\title{
COMMUNICATION ETHICS IBN MISKAWAIH AND ITS RELEVANCE TO THE SOLVING OF MORAL PROBLEMS IN INDONESIA
}

\author{
Muhammad TaufiqHarahap \\ Email: mtaufiqhrp@gmail.com \\ State Islamic University of North Sumatra, Medan - Indonesia \\ Hasyimsyah \\ Email: hasyimsyah@uinsu.ac.id \\ State Islamic University of North Sumatra, Medan - Indonesia \\ Suwardi \\ Email: suwardi@gmail.com \\ State Islamic University of North Sumatra, Medan - Indonesia
}

\begin{abstract}
This research was in depth exploration of the concept of communication ethics and its relevance for the solving of the problems of Indonesian Moral formulated by IbnMiskawaih in his work The Tahdzib Al-Akhlak. In the study of communication science, these two things are interrelated. Communication ethics is an ethical standard for communicators and communicants in communication. From the topic above, there are several problems from the purpose of this study they are; knowing the views of IbnMiskawaih about ethics in terms of communication science perspective, knowing IbnMiskawaih's views on the ethics of verbal and non-verbal communication, knowing the view of IbnMiskawaih about the ethics of intrapersonal communication, Knowing IbnMiskawaih's views on the ethics of interpersonal communication, knowing IbnMiskawaih's view of the ethics of group communication, knowing IbnMiskawaih's view of the ethics of media communication, knowing IbnMiskawaih's view of the ethics of social communication, formulating the communication ethics of IbnMiskwaih and its Relevance for the solving of Moral problems in Indonesia. The research methodology was begun by putting the type of qualitative research with historical research and social research approaches to the study of excellent figures to explore the thoughts and views of a figure in the field. The figure intended here was IbnMaskawaih with descriptive method, which is a research procedure that produces the descriptive data in the form of written or oral words of the people and behave that can be observed directed at the background of individuals holistically that occurred in the past. The Tahdzib Al-Akhlak, the work of IbnMiskawaih contains and affirms communication ethics clearly and systematically. All the substance of the book was oriented to the communication ethics. The IbnMiskwaih writing has laid the verbal and nonverbal communication, intrapersonal communication, interpersonal communication, group communication and also mass communication. In the context of the solving of morality problems in Indonesia, the communication ethics written by Ibn Miskawaih in The Tahdzib Al-Akhlak was also became a strategic solution to be applied, moreover Indonesia is in the condition of multi dimensional moral degradation. The Tahdzib Al-Akhlak by Ibnmiskwaih contains thoughts and moral teachings that were based on the noble moral values, collaboration between the study of theoretical philosophy and practical guidance, where the segment of education and teaching were more prominent. So in this context, IbnMiskwaih communicated various thoughts as a solution approach. Firstly, moral degradation was changed through the education. Secondly,
\end{abstract}


the importance of education for children and adults. Thirdly, a fair leader in order to prevent the nation's moral degradation due to the role of a just leader is needed. Fourthly, the government's attention to the society became as the father's relationship with his son. Fifthly, choose a good friend as an effort to prevent the moral degradation. Sixthly, social virtue was also an important step in the solution of nation degradation. Seventhly, maintain mental health. This step was also quite strategic in solving the nation's degradation. At least internally there is an attempt to prevent the soul from becoming healthy and not easily contaminated with bad behaviors that can cause moral degradation in congregation.

Keyword: Moral, Ethics, Communication of Tahdzib al-AkhlakdanIbnMiskawaih

\section{INTRODUCTION}

A scholar as well as philosophers morality that concentrates on the field of moral philosophy named IbnMiskawayih, ${ }^{1}$ Has introduced the communication ethics with the concept: (1). View the importance of education for human beings in relation to the moral coaching. (2). Miskawaih argues that communication ethics plays a vital role in human interaction, whether with fellow human beings, the environment, or the organization. (3). Miskawayh states the possibility of human experience khuluq changes, and in terms of this is necessary the existence of the rules of shari'a, advice and various teachings about morals because humans with a sense can choose and distinguish which should be done and which should be abandoned. (4). For Ibn Miskawaih, ethical philosophy as a separate discipline is a methodological system for achieving good khuluq which publishes easy actions to achieve the ultimate goal: sa'adahabadiyah. (5). through a critical study of philosophy on the problems that cause the emergence of deviant behavior or criminal action, is expected to provide solutions to these problems. (6). Therefore, it is necessary first to know the essence of the concept of the soul (nafs) and its functions and its potentials, which, if used properly, will achieve high human dignity. It is also necessary to understand ways of maintaining the health of the nafs and diseases that pollute it. ${ }^{2}$

1Ibn Maskawaih was born in Iran in $330 \mathrm{H} / 932 \mathrm{AD}$ and died in $421 \mathrm{H} /$ 1030. Ibn Miskawayh spent all his life during the Abassiyyah caliphate lasting 524 years, from 132 to $654 \mathrm{H}$ / 750-1258 AD His full name is Abu Ali Ahmad Ibn Muhammad Ibn Maskawaip. Prior to entering Islam, Ibn Miskawayh was a Magi follower, believing in the stars.

${ }^{2}$ Saeful Anwar, Makalah: Ibnu Miskawaih dan Falsafat Akhlak http://irfanna.blogspot.com/search/label/Jurnal-Makalah-Penelitian/Ibnu_Miskawaihdan_Falsafat_Akhlak.htm), Accessed on June 1, 2013. 
The theory of Ibn Miskawaih is very interesting to be explored in depth. At least this communication ethics can be a solution in the degradation of moral degradation, as well as an effort to lift and develop new perspectives in science communication.

The purpose of this study is formulated as follows: 1) To know the view of Ibn Miskawaih about the ethics of communication. 2) To know the view of Ibn Miskawaih about the ethics of verbal and non verbal communication. 3) To know the view of Ibn Miskawaih about the ethics of intrapersonal communication. 4) To know the view of Ibn Miskawaih about the ethics of interpersonal communication. 5) To know the view of Ibn Miskawaih about the ethics of group communication. 6) To know the view of Ibn Miskawaih about the ethics of media communication. 7) To formulate the communication ethics of IbnMiskwaih and its Relevance For the Settlement of Morals Struggle in Indonesia.

\section{LITERATURE REVIEW}

Terms of ethics and ethics is a term that is sometimes equated meaning and sebahagian differentiated opinions of meaning. For these three terminology need to be described, so it looks the third red thread whether the three terms contain the same meaning or there are differences.

In terminology, various editors put forward by scholars and Muslim scholars. According to IbnMiskawaih, morality is the state of the soul that invites or encourages a person to do without being thought through and taken into account in depth. There are two kinds of perspectives: (1). Alamiyah and depart from character. For example the presence of an irritable person, because the smallest thing or who is afraid of small incidents. Also in people who are pounding due to a very weak voice that hit the eardrum, or fear of hearing the news or laughing too much just because of one extraordinary thing that amazed him, or saddened by things that did not overwhelm him. (2). Created through habit and practice. At first this state occurs because it is considered and considered, then through practice continuously, into character". 3

Al-Ghazali, said that the subject of ethical discussion covers all aspects of human life, both as individuals and groups. Viewed from all aspects of human life,

${ }^{3} \mathrm{Abu}$ Ali Akhmad Al - Miskawaih, Tahdzib Al-Akhlak (Lebanon, Beirut : Dar Al-Kutub, 1985) p. 265 
human actions can be categorized into two kinds, namely: First, the act of being born with the will and willful. Second, Acts born without will and not intentional. The types of first deeds include ethical deeds. Such deeds may be judged good or bad, because they are born with will and done willfully by the perpetrator. While the second type of action does not become the field of ethical object, because it can notbe judged good or bad. The act is a reflex motion that was born without a will and not done intentionally.

The formation of human characters whether to be good or bad character becomes an important study in ethics. Human character is not only formed just like that, but also caused by the factors or the basics that make up the behavior. These factors contributed to the printing and influence of human behavior. Various ethicists explain the basics of character formation by human, instinct, habit, descent, environment (milieu), will conscience (dlamir) and education. These factors are summarized in the descriptions below.

When talking about the characteristics of Islamic ethics, it also has its own characteristics and certainly different from the characteristics of the flow of philosophical ethics. According to Hamzah Jacob, the characteristics of Islamic ethics are: (a). Moral Resources (Qur'an and Sunnah). In Islamic ethics, the Qur'an and Sunnah serve as a moral source or basis of moral teaching. (B). the position of Intellect and Instinct, putting that sense and instinct into the basis of determining the good and bad of an action. (C). Motivation of Faith. This means that every good deed done by humans actually contained the value of worship in it. (D). The Chain of Morals Namely a relationship of faith motivation with the chains of akhlaq. ${ }^{4}(\mathrm{e})$. The Noble Purpose of Islamic Ethics. The ultimate goal of Islamic ethics, Islam teaches that the whole set of human life from beginning to death is solely dedicated to Allah SWT. There is an ethical relationship with the current evolving sciences of psychology, sociology, law, philosophy, fiqh, monotheism and communication science. This shows the original branch ethic of philosophy, but in its development is very touch and integrated with one another. It will not even be perfect to study a particular science without involving ethics.

${ }^{4}$ Ibid., p. $52-53$ 
The relationship of ethics and science communication is very strong and need each other. Communication is a branch of social science that is multidisciplinary, multidisciplinary nature of communication science caused by the object of observation communication studies in such a complex and related to other disciplines of science including ethics studies. If connected with ethics is definitely communication related to behavior. Moreover, humans who communicate must interact with other humans. Almost everyone needs social relationships with others, and this need occurs with the exchange of messages that serve as a bridge to unite humans without communicating to be isolated. The messages are surfaced through human behavior. Starting from waving, smiling, surly, nodding or giving a gesture, we are also behaving. Often these behaviors are messages. The messages are used to communicate something to someone. ${ }^{5}$

According to Richard L. Johannesen, ethical issues are always inherent in every form of communication between people so that communication is judged in the right and wrong dimensions always involve a meaningful influence on other human beings, so the communicator consciously chooses a particular goal to be achieved and ways of communicating to achieve that goal. ${ }^{6}$ Especially in communicating always experience the problem of ethics in various contexts. There is interpersonal communication, small group communication, public communication, organizational communication, mass communication and intercultural communication. Messages delivered can be verbal and non verbal (facial expressions, gestures, hands, intonation, even silence). This means that ethical communication is needed even though situational. ${ }^{7}$

\section{FINDINGS AND DISCUSSION}

As a result of the findings of this study there are several important points, it can be seen as follows:

Firstly, IbnMiskawaih has put the concept of communication ethics. Defenitiflbn Miskawaih does not define the ethics of communication, he only defines the ethics which he thinks is the state of the soul that causes the soul to act without

\footnotetext{
${ }^{5}$ Dedy Mulyana, Komunikasi Antar Budaya Panduan Berkomunikasi Dengan Orang-orang Berbeda Budaya, (Bandung: Rosdakarya, 2006), p. 12

${ }^{6}$ Richard L. Johannesen, Etika Komunikasi (Bandung : PT RemajaRosdakarya, 1996) p. 2

${ }^{7}$ Ibid., p. viii
} 
thought or considered in depth. This kedaan depart from the character and habit or practice. Yet when viewed and measured by communication theory clearly in his masterpiece Tahdzib Al-Akhlak (Moral Education) gives the message of communication ethics as seen in the exposition of this book that is to instill in us moral qualities and execute them in spontaneous main actions. To carry out that which should be a priority is human nature, the perfection of power and the purpose of his soul. The book of Tahdzib al - Akhlakwritten by IbnMiskawaih contains seven chapters. When viewed from one chapter to another chapter are interrelated. This shows that the feature of this book is in the "academic scholastic system" which means to be completely systemized.

Tahdzib Al-Akhlak by Ibn Miskawaih contains and affirms clear communication ethics. All the substance of the book beroreantsi to communication ethics. As mentioned Muhammad Mufid, ethics of communication is defined as the ethical standards used by communicators and communicants. What Ibn Miskawaih wrote in the book of Tahdzib al - Akhlak reflects and accommodates from the kinds and forms of communication science itself. It may be said that Ibn Miskwaih has laid out the various divisions of communication before we know it today. Such as verbal and nonverbal communication, intra personal communication, interpersonal communication, group communication, organizational communication and mass communication

Secondly, IbnMiskawaih lays down clearly the ethics of verbal communication. Communication delivered in writing using the language. Language was a set of words that have been structured into a set of sentences that contain meaning. The Book of Tahdzib Al - Akhlak was a manifestation of the ethics of verbal communication. What IbnMiskawaih writes in these seven chapters was a form of verbal communication. The language that he was delivered in Tahdzib Al - Akhlak was a set of symbols understood by all communities. The language of IbnMiskawaih in the book was the primary means of unifying his thoughts, feelings and intentions by using words in writing that present various aspects of the reality of life, whether it was happening or what will happen in the future. An example was seen in the introduction to the book Tahdzib al -Akhlak says: "Instill within us moral qualities and exercise in spontaneous primary actions. In doing so, the first thing to note is the nature, perfection, power and purpose of the soul. "IbnMiskawaih invited us all 
through verbal communication to uphold good deeds, while providing guidance for young people to always do Beneficial to avoid getting lost. The writings continue to flow in the form of guidance and advice on the importance of good etiquette in this life and to abstain from disgraceful acts that are indeed destructive to our own lives. The language function in the book Tahdzib Al - Akhlak is important. At least when associated with Larry L. Barker, languages have three functions: language as naming (naming or labeling), language as interaction, and language as information transmission. The three functions of the above language if associated with Tahdzib Al - Akhlak accommodate the three functions. In Tahdzib Al - Akhlak many languages in the form of naming affirmed by IbnMiskawaih and giving their own terms can be termed already popular or termed by IbnMiskwaih. For example the definition of soul, the parts of virtue, goodness is the midpoint, justice, love and friendship and others. Tahdzib Al-Akhlak contains an interaction function that emphasizes ideas and emotions. Almost all chapters of IbnMiskwaih's book offer ideas and emotions. For example Ibn Miskawaih describes mental illnesses, maintaining mental health and ways of healing mental illness. These are all important ideas that IbnMiskwaih offers. Tahdzib al-Akhlak also contains the function of transmission and informsi. It is very clear what is written in this book is a reality of the past, present and future. Moral study is an interesting topic and never disappeared by time and place. Because this is a part of humanitarian behavior, as long as a human being exists, morality continues to stick to the story of human life.

Thirdly, IbnMiskawaih lays down clearly the ethics of Intra Personal Communications communication. This model is a process of communication that occurs within a person with an invisible subject. This includes sensation, perception, memory and thinking. The book of Tahdzib al-Akhlak by IbnMiskwaih actually shows intra-personal communication. Ibn Miskawaih through thought, perception and memory poured it into Tahdzib al-Akhlak. Here is the spread of communication between IbnMiskwaih with his communicant at that time and to this day, although the object is not visible. All the material and substance of the book Tahdzib al-Akhlak is the process of information of his thoughts, perceptions and analysis of moral education, then he writes in Tahdzib Al-Akhlak which contains about: ethical principles, character and refinement of language, goodness and happiness, justice, Love and friendship and mental health. As an example of the interpersonal 
communication ethic laid by IbnMiskwaih is to describe the soul as: "The soul is not matter, matter does not contain other matter, because matter is in essence, forever contained as contained in other matter. He can never stand alone. Jauhar (atom) is forever a receiver (form). It is better than the payload for other forms. "IbnMiskwaih's thought above is the side of his mind laying the concept of the soul. He asserts the soul is not the body and not the body part, nor the state of the body, but something other than the body either in terms of substance, its judgment or its nature and its behavior. Surely this becomes interesting as a small sample of interpersonal communication that must be understood together

Fourthly, Ibn Miskawaih lays down clearly the ethics of Interpersonal Communication. Interpersonal communication in various views is seen from the perspective of the component, the perspective of realionaldiadic and the development perspective. Understanding by component means interpersonal communication by observing the main components. In this case the delivery of a message by one person and the receipt of a message by another person or a small group of people with various impacts and with opportunities to provide immediate feedback. Next is the communication perspective of the dyadic relationship defined as the communication that takes place between two people who have a steady and clear relationship. Like a child's relationship with father and so on.While communication perspective development is defined as the end of development and communication that is not personal at one extreme into personal communication or intimate at the other extreme.

The book of IbnMiskwaih'sTahdzb Al-Akhlak communicates interpersonal messages. At least this relationship is brought closer to Understanding by component, in the form of interpersonal communication by observing the main components. In this case the delivery of a message by one person and the receipt of a message by another person or a small group of people with various impacts and with opportunities to provide immediate feedback. In his time Ibn Miskawaih with his disciples and listeners at that time we call the communicant is an influential component in the book Tahdzib Al-Akhlak, In other hand, tahdzib Al-Akhlak also closer to the theory of communication effectiveness that states interpersonal communication using media and non media. Thus the book Tahdzib Al-Akhlak is part of the print media, although the reader does not meet face to face and physically 
dealing with Ibn Miskawaih, it is seen as a form of implementation of inter-personal communication. One of the excerpts that can be picked as a form of interpersonal communication of IbnMiskwaih is about the human obligation to its creator in the form of getting closer to AzzawaJalla by means of strong will and spirit, the essential sciences as well as the sure knowledge, the embarrassment of lies and the lack of The vigilance of the soul caused by neglect and diligence to perform these virtues is limited to its ability.

Fifthly, Ibn Miskawaih also laid the ethics of group communication (Group communication) which defined the process of communication that took place between three or more people face to face, where the interaction between each other with each other. Here there is no limit to the minimum number of people who are berkonuikasi. However, for the maximum number of no more than fifty people, Tahdzib Al-Akhlak written by Ibn Miskwaih also shows group communication. At least this is seen in two things: First, the process of communicating the mind, the feeling written in Tahdzib Al-Akhlak will not be separated by involving many communicants in small groups as well as in large groups. It could be in the group with his students, his congregation or those closest to his time, then communicate with each other in the form of discussion and dialogue. Moreover, the material of Tahdzib Al-Akhlak itself can not be separated from seeing warm events at that time. Second, the substance of Tahdzib Al - Akhlak itself teaches about group communication. This is seen from excerpts of the text communicated by IbnMiskwaih on the need to mingle and cooperate in achieving the good: "Because man's goodness and his talent are many in the soul and because one can not achieve them all. Then need to join a large group to achieve all this. "

Sixthly, IbnMiskawaih lays down the ethics of mass communication. Mass communication is the official means and channels as a means of communication to spread the news and messages to the wider community. Joseph A. Devito explains the forms of mass communication consisting of television, radio, newspapers, magazines, books, and audio recordings - cassettes, records or compact disks. Tahdzib Al-AkhlakIbnMiskwaih is a form of mass communication. Quoting what Joseph A. Devito affirmed, one form of mass communication is through books. Tahdzib Al-Akhlak is a book / book written by IbnMiskwaih in the form of mass communication. In other words the entire substance of Tahdzib al Akhlak begins the 
principles of ethics, character and subtlety of language, goodness and happiness, justice, love and friendship and mental health are all forms of mass communication IbnMiskawaih.

Seventhly, the Communication Ethics of IbnMiskwaih in the settlement of nation degradation is also an important point in this paper. Indonesia's moral degradation is experiencing a multi-dimensional crisis, although technological developments have indeed succeeded in advancing human civilization. However, behind the glitter of this worldly life, precisely the moral and moral crisis in the life of society, nation and state, this moral crisis is increasingly worrisome and will have bad implications in various dimensions of the political, economic, social, cultural and defense life of the nation and the nation in the future. If the solution is linked to the ethical degradation of the community with the approach of communication is a strategic direction. Communication is a mechanism to socialize cultural norms of society, either horizontally from society to society, or vertically from one generation to the next. On the other hand, culture establishes norms (communications) that are considered appropriate for a group, such as not against parents, sitting politely and others. However, communications those are instrumental to convey these norms so that influential in the change of attitude of the communicant.

\section{CONCLUSION}

IbnMiskawaih through Tahdzib Al-Akhlak offers the idea of the concept of ethical communication of the nation's moral degradation settlement. IbnMiskwa'sTahdzibAl-Akhlak contains thoughts and moral teachings based on the noble moral values that combine between theoretical philosophical studies and practical guidance, in which the facets of education and teaching are more prominent. So in this context, IbnMiskwaih communicates various thoughts to serve as a solution approach:

(a) Moral degradation is changed through education. As IbnMiskwaih introduces his theory with the concept of character can be changed through education.

(b) Education of children and adolescents. In explaining this theory IbnMiskwaih writes the process of human development from birth, children to adults.

(c) Fair Leaders. In order to stem the nation's moral degradation, the role of a just leader is needed. 
(d) Government's concern with the people. The government's relationship with the people also focused on being described by Ibn Miskawaih in Tahdzib Al-Akhlak. He put the relationship between the king / head of state with the people, he called the father relationship with his son. The king is a father and a people as a child; of course the relationship is quite close and inseparable from each other and the same rights and duties.

(e) Selecting friends. Stemming moral degradation can be done and anticipated by choosing friends. Besides that also need to maintain friendship ethics and create good friendship, attention not conflict and keep unity with friend.

(f) Social virtue is also an important step in the settlement of national degradation. Moral virtue becomes a strategic value in the interaction of human interaction. As well as rejecting people who behave ascetic practices trying to distance themselves from the wider community. This does not create virtue in society.

(g) Maintain mental health. This step is also quite strategic in solving the nation's degradation. At least internally there is an attempt to prevent the soul from becoming healthy and not easily contaminated with bad behaviors that can cause moral degradation in congregation.

\section{BIBILIOGRAPHY}

Abu Ali Akhmad Al - Miskawaih, (1985). Tahdzib Al-Akhlak. Lebanon, Beirut: Dar Al-Kutub

Anwar, S. (2013). Makalah: Ibnu Miskawaih dan Falsafat Akhlak. (http://irfanna.blogspot.com/search/label/Jurnal-Makalah-Penelitian/Ibnu_Miskawaihdan_Falsafat_Akhlak-.htm). Diakses tanggal 1 Juni 2013.

Johannesen, R. L (1996).Etika Komunikasi. Bandung: RemajaRosdakarya.

Mulyana, D. (2006). Komunikasi Antar Budaya Panduan Berkomunikasi Dengan Orangorang Berbeda Budaya. Bandung: Rosdakarya 